\title{
Pengetahuan Mempengaruhi Stigma Tokoh Agama Terhadap Orang Dengan HIV/AIDS (ODHA) di Kabupaten Banyumas
}

\author{
Misrina Retnowati*), Sutopo Patria Jati**), Syamsulhuda BM$^{* * *}$ ) \\ *) Akademi Kebidanan YLPP Purwokerto \\ Korespondensi : aqilahasya@yahoo.co.id \\ **) Magister Ilmu Kesehatan Masyarakat Universitas Diponegoro Semarang \\ ***) Magister Promosi Kesehatan Universitas Diponegoro Semarang
}

\begin{abstract}
ABSTRAK
Tingkat penyebaran HIV/AIDS yang semakin mengkhawatirkan, memerlukan penanggulangan secara terpadu dari berbagi pihak, baik pemerintah, lembaga swadaya masyarakat, termasuk tokoh agama. Pemuka agama diyakini memegang peranan strategis untuk menanggulangi dampak buruk, sekaligus memutus mata rantai penyebaran HIV dan AIDS. Penelitian ini bertujuan untuk mengetahui faktor-faktor yang mempengaruhi stigma tokoh agama terhadap ODHA. Penelitian ini merupakan penelitian analitik dengan pendekatan cross sectional. Pengambilan data dilakukan pada 164 tokoh agama di Kabupaten Banyumas. Analisis data univariat menggunakan distribusi frekuensi, analisis bivariat menggunakan chi square dan analisis multivariat menggunakan uji regresi logistik. Hasil penelitian menunjukkan bahwa faktor yang berhubungan dengan stigma tokoh agama terhadap ODHA adalah nilai/kepercayaan, pengetahuan tentang HIV/AIDS dan dukungan teman. Faktor yang paling dominan adalah pengetahuan tentang HIV/AIDS. Dari penelitian ini dapat disimpulkan bahwa pengetahuan tentang HIV/AIDS dapat mempengaruhi stigma terhadap ODHA selain dukungan teman dan nilai / kepercayaan.
\end{abstract}

Kata kunci: Stigma terhadap ODHA, Pengetahuan Tentang HIV/AIDS, Toma

\section{ABSTRACT}

Knowledge about HIV/AIDS Influencing The stigma towards people living with HIV in Banyumas. The rate of the spread of HIV/ AIDS that more and more worrisome needs an integrated tackling from various parties such as the government, non - governmental organizations, includes religious figures. Religious leader is believed that they have a strategic role in tackling the bad effect, at the same time break the chain of the spread of HIV and AIDS. This research aimed to know the factors that influence the stigma of religious figures towards people living with HIV/ AIDS. The kind of the research isanalytical correlational with crossectional approach. The data was collected from 164 the religious figures. Data were analyzed using univariate with frequency distribution, bivariate with Chi-square, and multivariate with logistic regression. The result showed that factors related to The stigma towards people living with HIV were knowledge about HIV/AIDS, value/belief and friend's support. Knowledge about HIV/AIDS was the main factor that has considerable influence to The stigma towards people living with HIV. From this research, can be conclude that Knowledge about HIV/AIDS can affect The stigma towards people living with HIV besides value/belief and friend's support.

Keywords : The stigma towards people living with HIV, knowledge, religious figures 
PENDAHULUAN

Kebijakan dan program penanggulangan HIV/AIDS telah banyak dilakukan di Indonesia, namun pelaksanaannya masih terkendala. Kendala tersebut antara lain masih terbatasnya jangkauan dan kualitas program yang ditengarai telah menghambat efektivitas program dalam pengendalian epidemi. Berbagai faktor yang ditengarai melatarbelakangi efektivitas program, antara lain aspek sosial budaya termasuk stigma dan diskriminasi (KNPP RI, 2008)

Stigma dan diskriminasi adalah salah satu tantangan yang berat dalam program pencegahan penularan HIV/AIDS. Berdasarkan hasil survei yang dilakukan oleh Badan Pusat Statistik (BPS) tahun 2009 bahwa stigma dan diskriminasi yang dialami orang terinfeksi HIV bisa datang dari berbagai kelompok masyarakat. Mulai dari lingkungan keluarga, lingkungan tempat tinggal, lingkungan kerja, lingkungan sekolah, serta lingkungan komunitas lainnya. Bahkan sering terjadi diskriminasi di layanan kesehatan terhadap orang yang terinfeksi HIV saat mereka mendapatkan perawatan kesehatan. (KPAN, 2009)

Pada kenyataannya informasi tentang HIV/AIDS melalui berita di media massa, ceramah keagamaan dan lain-lain, selalu saja menyebutkan HIV/AIDS karena 'seks bebas', zina, dan lain-lain. Tanpa disadari hal ini justru mendorong stigma dan diskriminasi terhadap ODHA. Bahkan di daerah Kecamatan Lumbir, Wangon dan Purwokerto Selatan Kabupaten Banyumas tokoh agama tidak bersedia memandikan jenazah ODHA. (LPPSLH, 2014). Masih adanya stigma dan diskriminasi masyarakat terhadap ODHA, berdampak pula ketika ODHA meninggal dunia, sehingga tidak mendapatkan perawatan sebagaimana mestinya. Hal tersebut terjadi karena minimnya informasi yang didapat tentang HIV/AIDS. Bahkan pada jenazah ODHA terkadang masih ada diskriminasi sehingga masyarakat enggan untuk mengantar dan mendoakan mereka, sehingga berakibat terhadap kehidupan sosial dan psikologi keluarga (Nasarrudin, 2009)

Stigma terhadap ODHA masih banyak terjadi di masyarakat. Hal ini terlihat dari hasil penelitian yang menunjukkan hampir separuh dari responden $(49,7 \%)$ memiliki sikap negatif terhadap ODHA. Bentuk stigma di antaranya tidak bersedia makan makanan yang disediakan atau dijual oleh ODHA, tidak membolehkan anaknya bermain bersama dengan anak HIV, tidak mau menggunakan toilet bersama dengan ODHA, bahkan menolak untuk tinggal dekat dengan orang yang menunjukkan gejala HIV/AIDS. (Shaluhiyah, 2015)

Stigma memberikan tekanan dengan berbagai cara yang tidak kelihatan 
terhadap ODHA namun bisa membuat Timur, DKI Jakarta, Bali, dan Jawa Barat perasaan ODHA terpukul dan malu. (Kemenkes RI, 2014)

Sedangkan diskriminasi memberikan

Data dari Dinas Kesehatan tekanan dengan cara yang kelihatan dengan Kabupaten Banyumas sampai dengan bulan berbagai cara yang membuat ODHA harus Juli 2014 didapatkan data kasus HIV menanggung perasaan malu. Sebagai sebanyak 1.088 orang dan kasus AIDS 535 akibatnya selanjutnya ODHA menutup diri untuk tidak mau membuka status HIVnya dan bahkan putus asa. Sebaliknya bagi orang yang belum tahu status HIVnya tidak akan mau untuk mengikuti tes HIV di klinik VCT. Disisi lain ODHA yang menutup diri yang tidak mau membuka status HIVnya kepada pasangannya (suami atau istri/ sebagai partner seks) akan menularkan HIV kepada pasangannya. Hal yang sama terjadi pada orang yang sudah terinfeksi namun belum mengetahui status HIVnya apakah positif atau tidak. Fenomena ini tergambar dalam penemuan kasus HIV yang selalu terjadi setelah orang menderita infeksi oportunistik dan dilakukan tes HIV ternyata positif. (KPAN, 2009)

Data Kementerian Kesehatan Republik Indonesia Triwulan II Tahun 2014 menunjukkan bahwa jumlah kumulatif kasus HIV yang terjadi di Indonesia sampai dengan bulan Juni tahun 2014 adalah 142.950 kasus dan jumlah kumulatif kasus AIDS 55.623 kasus. Demikian halnya dengan kasus HIV/AIDS yang terjadi di Jawa Tengah yang juga sangat memprihatinkan dimana Jawa Tengah menempati urutan ke-6 setelah Papua, Jawa orang. Dimana kasus HIV terbanyak pada kelompok usia 25-34 tahun sebesar 52,6\%. (Dinkes Banyumas, 2014). Dari data diatas dapat dilihat bahwa kasus HIV/AIDS semakin meningkat dari tahun ke tahun. Oleh karena itu, upaya penanggulangan HIV/AIDS menjadi sangatlah penting (KNPP RI, 2008)

Permasalahan stigma dan diskriminasi terhadap ODHA harus segera diatasii agar kegiatan dan pencegahan dan penanggulangan HIV/AIDS dapat dilaksanakan dengan efektif. Salah satu cara yang perlu dilakukan adalah melibatkan tokoh agama untuk membantu memberi pemahaman kepada masyarakat tentang masalah HIV/AIDS (Kelly, 2003)

Tokoh agama merupakan aktor penting di masyarakat karena mempunyai legitimasi dan tinggal dalam waktu lama di masyarakat yang bersangkutan. Para tokoh agama juga dianggap dapat memainkan peranan penting dalam mengubah persepsi masyarakat terhadap HIV/AIDS. Selain itu, tokoh agama dianggap dapat meningkatkan kesadaran masyarakat mengenai transmisi HIV/AIDS, pengurangan stigma dan diskriminasi terhadap ODHA. Mereka juga 
dapat dilibatkan untuk membantu menjamin bahwa ODHA dapat memperoleh perawatan dan dukungan yang memadai. Tokoh agama mempunyai posisi yang memadai untuk mempengaruhi sikap publik maupun kebijakan nasional. Kondisi seperti itu juga ditemukan di Malaysia dan Thailand di mana tokoh agama mampu berperan dalam mengurangi cepatnya pertumbuhan jumlah kasus HIV/AIDS (FHI, 2007)

Tokoh masyarakat merupakan salah satu faktor lingkungan sosial memiliki peranan penting terjadinya stigma terhadap ODHA. Apabila seorang tokoh masyarakat memberikan stigma terhadap ODHA, masyarakat di sekitarnya memiliki kemungkinan juga akan terpengaruh untuk melakukan hal yang sama. Reaksi masyarakat terhadap ODHA memiliki efek besar pada ODHA. Apabila reaksi masyarakat bermusuhan, seorang penderita HIV dapat merasakan adanya diskriminasi dan kemungkinan dapat meninggalkan rumah atau menghindari aktivitas sehari-hari seperti berbelanja, bersekolah, dan bersosialisasi dengan masyarakat. Pada dasarnya, tokoh masyarakat berperan penting dalam menurunkan terjadinya stigma dan diskriminasi terhadap ODHA karena tokoh-tokoh lokal merupakan model atau contoh yang biasanya menjadi panutan masyarakat, terutama pada masyarakat di daerah pedesaan. Tindakan dan sikap mereka dijadikan referensi oleh masyarakat dalam mengubah perilaku sehat, termasuk yang terkait dengan penularan HIV, dan menurunkan stigma terhadap ODHA. Oleh karena itu, pemberian informasi yang komprehensif tentang HIV/AIDS kepada tokoh masyarakat menjadi sangat penting dilakukan oleh petugas kesehatan, agar tokoh masyarakat dapat menularkan dan menyebarkan informasi yang benar kepada masyarakat, termasuk tentang menghilangkan stigma terhadap ODHA. (Shaluhiyah, 2015)

Pengetahuan adalah merupakan hasil dari tahu dan ini terjadi setelah orang melakukan penginderaan terhadap suatu obyek tertentu. Sebagian besar pengetahuan manusia diperoleh melalui mata dan telinga (Notoatmodjo, 2007). Dengan pengetahuan tokoh agama yang memadai dan persepsi terhadap HIV/AIDS positif diasumsikan akan dapat menciptakan kondisi yang dapat mengurangi stigma dan diskriminasi terhadap ODHA.

Faktor yang mempengaruhi pengetahuan tokoh agama tentang HIV/AIDS adalah keterlibatan tokoh agama dalam sosialisasi HIV/AIDS yang berupa penyuluhan tentang HIV/AIDS atau kegiatan sarasehan terkait permasalahan HIV/AIDS. Tokoh agama yang pernah terlibat dalam kegiatan sosialisasi tentang HIV/AIDS menghasilkan tidak hanya peningkatan pengetahuan tetapi juga peningkatan sikap yang lebih baik terhadap 
ODHA (Notoatmodjo, 2007).

Berdasarkan uraian tersebut, dapat ditarik suatu permasalahan bagaimana pengaruh pengetahuan terhadap stigma tokoh agama terhadap orang dengan HIV/AIDS (ODHA). Pernyataan tersebut diperkuat oleh L.Green yang mencoba menganalisis perilaku manusia berangkat dari tingkat kesehatan. Faktor perilaku ditentukan atau dibentuk oleh faktor Predisposisi (Predisposing factor), faktor pemungkin (Enabling factor) dan faktor penguat (reinforcing factor). (Green, 1999).

\section{METODE}

Jenis penelitian ini adalah penelitian analitik korelasional menggunakan metode survei dengan pendekatan cross-sectional. Penelitian ini dilaksanakan pada bulan Januari tahun 2015 pada tokoh agama di Kabupaten Banyumas. Populasi dalam penelitian sebanyak 278 tokoh agama. Penentuan jumlah sampel dalam penelitian ini menggunakan rumus Slovin didapatkan hasil sebanyak 164 tokoh agama. Teknik sampling yang digunakan dalam penelitian ini adalah proportional random sampling yaitu pengambilan sampel anggota populasi dilakukan secara acak dengan melihat strata yang ada (agama islam, kristen katolik, kristen protestan, hindu dan budha). Variabel independen dalam penelitian ini adalah karakteristik (umur, pendidikan dan pekerjaan), sosialisasi tentang HIV/AIDS, nilai/kepercayaan, dukungan teman dan pengetahuan tentang HIV/AIDS. Alat penelitian yang digunakan adalah kuesioner. Pengumpulan data dilakukan dengan metode wawancara. Hasil penelitian dianalisis secara univariat, bivariat dan multivariat. Analisis univariat menggunakan distribusi frekuensi, analisis bivariat menggunakan chi-square dan analisis multivariat menggunakan regresi logistik.

\section{HASIL DAN PEMBAHASAN}

Tabel 1. Distribusi Frekuensi Stigma Tokoh Agama Terhadap ODHA Berdasarkan Karakteristik, Pengetahuan Tentang HIV/AIDS, Nilai / Kepercayaan dan Dukungan Teman

\begin{tabular}{ccccc}
\hline Variabel & f & Melakukan & $\begin{array}{c}\text { Tidak } \\
\text { melakukan }\end{array}$ & $\begin{array}{c}\text { P } \\
\text { value }\end{array}$ \\
\hline Umur & $135(82,3 \%)$ & $73(54,1 \%)$ & $62(45,9 \%)$ & 0,432 \\
40-60 tahun & $29(17,7 \%)$ & $18(62,1 \%)$ & $11(37,9 \%)$ & \\
$\quad \geq 61$ tahun & & & & \\
Pendidikan & $137(83,5 \%)$ & $78(56,9 \%)$ & $59(43,1 \%)$ & 0,401 \\
$\quad$ Menengah & $27(16,5 \%)$ & $13(48,1 \%)$ & $14(51,9 \%)$ & \\
Tinggi & & &
\end{tabular}




\begin{tabular}{|c|c|c|c|c|}
\hline \multicolumn{5}{|l|}{ Pekerjaan } \\
\hline Tidak bekerja & $16(9,8 \%)$ & $11(68,8 \%)$ & $5(31,2 \%)$ & 0,286 \\
\hline Bekerja & $146(90,2 \%)$ & $80(54,1 \%)$ & $66(45,9 \%)$ & \\
\hline \multicolumn{5}{|l|}{ Sosialisasi HIV/AIDS } \\
\hline Pernah & $77(47 \%)$ & $36(46,8 \%)$ & $41(53,2 \%)$ & 0,334 \\
\hline Tidak pernah & $87(53 \%)$ & $55(63,2 \%)$ & $32(36,8 \%)$ & \\
\hline Pengetahuan & & & & \\
\hline \multicolumn{5}{|l|}{ HIV/AIDS } \\
\hline Baik & $67(40,9 \%)$ & $26(38,8 \%)$ & $41(61,2 \%)$ & 0,000 \\
\hline Kurang & $97(59,1 \%)$ & $65(67 \%)$ & $32(33 \%)$ & \\
\hline \multicolumn{5}{|l|}{ Kepercayaan/nilai } \\
\hline Baik & $81(49,4 \%)$ & $21(25,9 \%)$ & $60(74,1 \%)$ & 0,009 \\
\hline Kurang & $83(50,6 \%)$ & $70(84,3 \%)$ & $13(15,7 \%)$ & \\
\hline \multicolumn{5}{|l|}{ Dukungan Teman } \\
\hline Mendukung & $70(42,7 \%)$ & $20(28,6 \%)$ & $50(71,4 \%)$ & 0,013 \\
\hline Tidak Mendukung & $94(57,3 \%)$ & $71(75,5 \%)$ & $23(24,5 \%)$ & \\
\hline \multicolumn{5}{|l|}{ Stigma Tokoh Agama } \\
\hline Melakukan & $91(55,5 \%)$ & - & - & - \\
\hline Tidak Melakukan & $73(44,5 \%)$ & - & - & - \\
\hline
\end{tabular}

Tabel 2. Hasil Analisis Regresi Logistik Stigma Tokoh Agama Terhadap ODHA

\begin{tabular}{lcccc}
\hline \multicolumn{1}{c}{ Variabel } & Koefisien & P & OR & $\begin{array}{c}\text { 95\% confidence } \\
\text { interval (CI }\end{array}$ \\
\hline Pengetahuan & 2,561 & 0,009 & 4,276 & $0,836-27,148$ \\
Kepercayaan & 1,532 & 0,035 & 0,816 & $0,085-0,549$ \\
Dukungan Teman & 1,735 & 0,049 & 0,434 & $0,006-0,090$ \\
Konstanta & 2,059 & 0,823 & 0,006 & \\
\hline
\end{tabular}

\section{Karakteristik responden}

Tabel 1 memperlihatkan karakteristik responden dalam penelitian ini adalah sebagian besar responden berumur 40-60 tahun (82,3\%) dan sebanyak 83,5\% responden berpendidikan menengah (SMA). value >0,05 sehingga tidak memenuhi Karena dari latar belakang pendidikan SMA syarat untuk dilakukan analisis multivariat. sebagian besar responden bekerja $(90,2 \%)$. Dari analisis bivariat karakteristik responden didapatkan hasil $\mathrm{p}$ value umur $0,432, \mathrm{p}$ value pendidikan 0,401 dan $\mathrm{p}$ value pekerjaan 0,286 . Ketiga variabel karakteristik responden $p$ value $>0,05$ yang maka seseorang akan lebih berpengalaman, artinya tidak ada hubungan umur, pendidikan dan pekerjaan dengan stigma tokoh agama terhadap ODHA. Untuk karakteristik responden tidak dilakukan analisis multivariat karena untuk nilai $\mathrm{p}$ Umur adalah usia yang menjadi indikator dalam kedewasaan setiap pengambilan keputusan untuk melakukan sesuatu yang mengacu pada setiap pengalamannya. Semakin tua umur seorang 
karena umur seseorang akan mempengaruhi kinerja, semakin lanjut umurnya, maka semakin lebih bertanggung jawab, lebih tertib, lebih berbakti daripada usia muda. Tidak adanya hubungan antara umur dengan stigma tokoh agama terhadap ODHA disebabkan karena dengan semakin bertambahnya usia seseorang, tidak menjamin bahwa dia semakin dewasa. Karena kedewasaan seseorang tidak ditentukan oleh usia, tapi bagaimana cara menyelesaikan masalahnya dengan kepala dingin, bagaimana caranya mengambil setiap keputusan yang tepat dan setiap kesempatan yang ada dalam hidupnya. Dalam hal ini dikaitkan dengan perilaku menghadapi ODHA. (Hurlock, 2008)

Pendidikan adalah kemahiran menyerap pengetahuan pendidikan seseorang berhubungan dengan sikap seseorang terhadap pengetahuan yang diserapnya. Semakin tinggi tingkat pendidikan semakin mudah untuk dapat menyerap pengetahuan. Semakin tinggi pendidikan seseorang, maka akan semakin mudah untuk menyerap informasi dalam bidang kesehatan. Tidak ada hubungan pendidikan dengan stigma tokoh agama terhadap ODHA menunjukkan bahwa perilaku seseorang bukan hanya dipengaruhi oleh tingkat pendidikan di bangku sekolah saja namun banyak diperoleh dari pengalaman hidup. (Wawan, 2010).

Bekerja merupakan satu kewajiban bagi setiap insan. Pekerjaan mempengaruhi terjadinya stigma dan diskriminasi karena seseorang yang sudah lama bekerja cenderung mempunyai wawasan yang lebih luas dan pengalaman yang lebih banyak, dimana hal ini memegang peranan penting dalam perubahan perilaku seseorang. Hasil penelitian ini membuktikan bahwa tokoh agama yang bekerja atau tidak bekerja dapat melakukan stigma karena banyak faktor yang mempengaruhi stigma selain pekerjaan yaitu pengetahuan, nilai/kepercayaan dan dukungan teman. (Wawan, 2010)

Tabel 2 menunjukkan hasil analisis regresi logistik. Dari 7 variabel, yang memenuhi syarat untuk dilakukan analisis regresi logistik ada 3 variabel yaitu pengetahuan tentang HIV/AIDS, nilai / kepercayaan dan dukungan teman dengan $\mathrm{p}$ value $<0,05$. Setelah dianalasis regresi logistik didapatkan hasil variabel pengetahuan tentang HIV/AIDS memiliki pengaruh terhadap stigma terhadap ODHA dengan odds ratio 4,276 (nilai $\mathrm{p}=0,00995 \%$ CI : 0,836-27,148) yang artinya responden yang memiliki pendidikan kurang memiliki kecenderungan 4,276 kali lebih besar untuk melakukan stigma terhadap ODHA dibandingkan dengan responden yang memiliki pengetahuan baik.

Hal ini sesuai dengan apa yang dikatakan Notoatmodjo, setelah orang melakukan penginderaan terhadap objek 
tertentu baik melalui panca indera manusia yaitu indera penglihatan, penciuman, rasa dan raba yang sebagian besar berasal dari indra penglihatan dan pendengaran akan mendapatkan hasil yang berupa rasa tahu yang disebut pengetahuan. Tingkat pengetahuan seseorang juga mempengaruhi persepsi dan perilaku individu yang mana makin tinggi pengetahuan seseorang maka makin baik menafsirkan sesuatu. (Notoatmodjo, 2007)

Pengetahuan yang kurang inilah yang dapat menciptakan stigma serta diskriminasi terhadap ODHA. Tokoh agama hanya mengetahui HIV/AIDS itu merupakan sebatas penyakit menular dan sangat berbahaya dan belum memahami secara benar cara penularaanya. Ketidakpahaman ini menimbulkan stigma yaitu tokoh agama tidak mau memandikan jenazah ODHA dan tidak mau menganjar jenazah sampai tempat pemakaman.

\section{Sosialisasi HIV/AIDS}

Hasil penelitian menunjukkan bahwa lebih banyak responden yang tidak pernah mengikuti sosialisasi tentang HIV/AIDS sebanyak 53\%. Berdasarkan analisis bivariat diperoleh nilai $\mathrm{p}$ sebesar 0,334 yang artinya tidak ada hubungan antara sosialisasi dengan stigma tokoh agama terhadap ODHA. Untuk variabel sosialisasi HIV/AIDS tidak dilakukan analisis multivariat karena nilai $\mathrm{p}$ value >
0,05 sehingga tidak memenuhi syarat untuk dilakukan analisis multivariat.

Sosialisasi adalah penyebarluasan informasi (program, kebijakan, peraturan) dari satu pihak (pemilik program, kebijakan, peraturan) kepada pihak-pihak lain (aparat, masyarakat, yang terkena program dan masyarakat umum. Sosialisasi merupakan aktivitas komunikasi yang bertujuan untuk menciptakan perubahan pengetahuan, sikap dan perilaku sasaran terhadap ide pembaharuan (inovasi) yang ditawarkan. Sosialisasi program tersebut sangat penting, karena apabila sosialisasi program tersebut kurang baik, maka implementasi program tersebut bisa tidak berhasil. Tidak adanya hubungan antara sosialisasi dengan stigma kemungkinan disebabkan karena banyak faktor yang lebih berpengaruh terdapat stigma selain sosialisasi misalnya dukungan teman, pengetahuan dan kepercayaan. Jadi meskipun tujuan dari sosialisasi untuk meningkatkan pengetahuan tetapi kurang mendapat respon yang baik oleh tokoh agama. (Wawan, 2010)

\section{Pengetahuan Tentang HIV/AIDS}

Pada pengetahuan tentang HIV/AIDS, sebanyak $59,1 \%$ responden memiliki pengetahuan kurang. Beberapa pengetahuan responden yang masih salah tentang HIV/AIDS diantaranya adalah responden menjawab virus HIV/AIDS dapat menular melalui berenang $(73,2 \%)$, melalui 
berciuman $(70,1 \%)$ dan melalui bersin/batuk $(67,1 \%)$ dari jawaban tersebut responden belum memahami cara penularan HIV/AIDS dengan benar. Pada analisis bivariat diperoleh hasil nilai $\mathrm{p}=0,000$, yang berarti bahwa pengetahuan tentang HIV/AIDS memiliki hubungan yang signifikan dengan stigma terhadap ODHA.

Sejalan dengan penelitian yang dilakukan Rogers yang menyatakan bahwa pengetahuan atau kognitif merupakan domain yang sangat penting untuk terbentuknya tindakan seseorang. Perilaku yang didasari oleh pengetahuan dan sikap yang positif maka perilaku tersebut akan bersifat langgeng. Perilaku seseorang dipengaruhi oleh pengetahuan sebagai faktor predisposisi. Pengetahuan merupakan hasil tahu yang terjadi setelah seseorang melakukan pengindraan terhadap objek tertentu. Ketika seseorang mempunyai pengetahuan yang benar dan mengetahui manfaat suatu tindakan maka hal ini akan mempengaruhi dirinya sehingga tindakan yang dilakukan akan lebih langgeng. (Hurlock, 2008)

Hal ini sesuai dengan apa yang dikatakan Notoatmodjo, setelah orang melakukan penginderaan terhadap objek tertentu baik melalui panca indera manusia yaitu indera penglihatan, penciuman, rasa dan raba yang sebagian besar berasal dari indra penglihatan dan pendengaran akan mendapatkan hasil yang berupa rasa tahu yang disebut pengetahuan. Tingkat pengetahuan seseorang juga mempengaruhi persepsi dan perilaku individu yang mana makin tinggi pengetahuan seseorang maka makin baik menafsirkan sesuatu. (Notoatmodjo, 2007)

Pengetahuan tentang HIV/AIDS sangat mempengaruhi bagaimana individu tersebut akan bersikap terhadap ODHA. Stigma dan diskriminasi terhadap ODHA muncul berkaitan dengan ketidaktahuan tentang mekanisme penularan HIV, perkiraan risiko tertular yang berlebihan melalui kontak biasa dan sikap negatif terhadap kelompok sosial yang tidak proporsional yang dipengaruhi oleh epidemi HIV/AIDS ini. (Mahendra, 2006)

Pengetahuan yang memadai diasumsikan akan mengubah persepsi tokoh agama terhadap HIV/AIDS menjadi positif. Jika pengetahuan pemuka agama sudah memadai dan persepsi terhadap HIV/AIDS positif diasumsikan pemuka agama akan terlibat dalam upaya penanggulangan HIV/AIDS dan akan menciptakan kondisi yang dapat mengurangi stigma dan diskriminasi terhadap HIV/AIDS. Pengetahuan dan persepsi positif tersebut diasumsikan akan dapat ditularkan pada masyarakat luas atau umatnya. Dengan demikian maka stigma dan diskriminasi terhadap ODHA akan dikurangi dan pada akhirnya upaya pencegahan dan penanggulangan HIV/AIDS akan berjalan 
dengan efektif. (Russel, 2011).

\section{Nilai / Kepercayaan}

Stigma terhadap ODHA ini juga ditunjang dengan responden yang memiliki nilai/kepercayaan kurang sebanyak 50,6\%. Kepercayaan yang masih melekat pada responden diantaranya adalah responden menyatakan bahwa orang baik tidak mungkin terkena HIV/AIDS $(84,1 \%)$ dan tidak menyukai ODHA karena sudah pasti dia tertular HIV/AIDS karena perilakunya yang tidak baik (80,5\%). Responden masih mempercayai bahwa HIV/AIDS hanya dapat menyerang ke orang yang mempunyai perilaku tidak baik, yang perilakunya baik tidak mungkin tertular HIV/AIDS. Hasil analisis bivariat pada variabel nilai/kepercayaan juga memiliki nilai $\mathrm{p}=$ 0,009 . Sehingga dapat dinyatakan bahwa nilai/kepercayaan memiliki hubungan yang signifikan dengan stigma terhadap ODHA.

Peran agama dalam semua aspek kehidupan manusia sudah ada sejak berabad-abad yang lalu. Kepatuhan terhadap nilai-nilai agama para pemimpin agama mempunyai peran dalam pencegahan dan pengurangan penularan HIV. HIV/AIDS tidak hanya menyentuh tataran kesehatan namun juga masuk ke segala bidang termasuk masalah keyakinan atau agama. Banyaknya orang yang memiliki pemahaman yang minim serta pemahaman yang salah akan HIV/AIDS menyebabkan penyakit tersebut menjadi sumber stigma dan diskriminasi. Belum lagi adanya anggapan bahwa HIV/AIDS dianggap penyakit kutukan dan hukuman Tuhan serta dikaitkan dengan moral seseorang. Agama datang untuk memberikan pencerahan dan kedamaian. Agama memandang bahwa penyakit yang diderita oleh seseorang justru bila diterima dengan ikhlas dapat menggugurkan dosa-dosanya. Agama melarang hubungan seks lelaki dengan lelaki (Gay) serta perzinaan (Chinn, 2005).

Nilai merupakan sesuatu yang abstrak, yang dijadikan pedoman serta prinsip - prinsip umum dalam bertindak dan bertingkah laku. Keterikatan orang atau kelompok terhadap nilai menurut Theodorson relatif sangat kuat dan bahkan bersifat emosional. Oleh sebab itu, nilai dapat dilihat sebagai tujuan kehidupan manusia itu sendiri. Setiap individu dalam melaksanakan aktifitas sosialnya selalu berdasarkan serta berpedoman kepada nilai-nilai atau sistem nilai yang ada dan hidup dalam masyarakat itu sendiri. Artinya nilai-nilai itu sangat banyak mempengaruhi tindakan dan perilaku manusia, baik secara individual, kelompok atau masyarakat secara keseluruhan tentang baik buruk, benar salah, patut atau tidak patut. Suatu nilai apabila sudah membudaya didalam diri seseorang, maka nilai itu akan dijadikan sebagai pedoman atau petunjuk di dalam bertingkah laku. Hal ini dapat dilihat dalam 
kehidupan sehari - hari, misalnya stigma terhadap ODHA. Jadi, secara universal, nilai itu merupakan pendorong bagi seseorang dalam mencapai tujuan tertentu (Andrewin, 2008).

\section{Dukungan Teman}

Hasil analisis menunjukkan bahwa sebagian besar responden tidak mendapat dukungan teman yaitu sebanyak $(57,3 \%)$, di bandingkan responden yang mendapat dukungan teman (42,7\%). Salah satu bentuk tidak mendapat dukungan teman adalah responden tidak pernah diajak teman untuk memberikan pondasi ketuhanan kepada ODHA (61\%). Manusia dalam peranannya sebagai makhluk sosial, selalu akan berinteraksi dengan orang lain. Semenjak dilahirkan, manusia sudah mempunyai naluri untuk hidup berkawan. Dalam kehidupan sehari-hari, interaksi manusia dengan orang di sekitarnya dapat berupa bantuan baik secara langsung ataupun secara tidak langsung. Begitu pula dengan dukungan yang diterima oleh individu. Dukungan sosial dapat berasal dari berbagai sumber seperti pasangan/kekasih, keluarga, teman, terapis, dokter, atau organisasi masyarakat (Samsuridjal, 2012).

Dukungan teman akan menciptakan lingkungan yang kondusif yang mampu memberikan motivasi maupun wawasan baru bagi tokoh agama dalam menghadapi ODHA. Dukungan teman terhadap tokoh agama dapat digunakan untuk memberikan motivasi kepada ODHA dalam meminimalkan tekanan psikososial yang dirasakan ODHA sehingga ODHA dapat memiliki gaya hidup yang lebih baik dan dapat memberikan respon yang lebih positif terhadap lingkungan sosialnya (Widayatun, 2009).

Namun pada kenyataannya banyak tokoh agama yang mempunyai penilaian negatif terhadap ODHA sehingga banyak yang kurang mendukung apabila ada kegiatan-kegiatan yang berhungan dengan ODHA.

\section{Stigma Tokoh Agama Terhadap Orang Dengan HIV/AIDS (ODHA)}

Tokoh agama yang melakukan stigma terhadap ODHA sebanyak 55,5\%. Bentuk stigma yang dilakukan adalah responden menyatakan tidak mau memandikan jenazah ODHA $(73,2 \%)$, tidak mau mengantar jenasah sampai ke pemakaman $(70,1 \%)$ dan tidak mau memimpin doa bagi ODHA (70,1\%). Kurangnya informasi tentang HIV/AIDS menyebabkan belum semua masyarakat memahami penularan HIV/AIDS dari satu orang ke orang lain secara benar apakah bisa tertular bila memegang, menyentuh atau berdekatan dengan jenasah ODHA.

Stigma pada ODHA adalah sebuah perlakuan negatif yang diberikan oleh masyarakat karena dianggap bahwa 
HIV/AIDS yang diderita sebagai akibat perilaku yang merugikan diri sendiri dan berbeda dengan penyakit akibat virus lain. Ditambah lagi kondisi ini diperparah karena hampir sebagian besar kasus penularan HIV pada ODHA disebabkan karena aktivitas seksual yang berganti-ganti pasangan. (Goffman, 2007).

Secara teori memang benar bahwa ODHA menyerang pada perilaku berisiko namun stigma yang umumnya dilekatkan pada ODHA adalah bahwa HIV yang ada di dalam tubuh mereka itu karena Azab dari Tuhan. Kalangan pemuka agama dan tokoh masyarakat yang sering membuat pernyataan ini sehingga turut memicu masyarakat luas memiliki pandangan yang sama. Hal ini yang kemudian membuat komunitas-komunitas yang dekat dengan aktifitas beresiko seperti pekerja seks, gay, transgender serta pengguna narkotika suntik seringkali menerima perlakuan yang tidak mengenakkan dan stigma sosial yang besar (Andrewin, 2008).

Orang-orang dengan infeksi HIV menerima perlakuan yang tidak adil (diskriminasi) dan stigma karena penyakit yang dideritanya. Stigma pada ODHA melekat kuat karena masyarakat masih memegang teguh nilai-nilai moral, agama dan budaya atau adat istiadat bangsa timur (Indonesia) di mana masyarakatnya belum/tidak membenarkan adanya hubungan di luar nikah dan seks dengan berganti-ganti pasangan, sehingga jika virus ini menginfeksi seseorang maka dianggap sebagai sebuah balasan akibat perilakunya yang merugikan diri sendiri. Hal ini terjadi karena masyarakat menganggap ODHA sebagai sosok yang menakutkan. Maka dari itu mencibir, menjauhi serta menyingkirkan ODHA adalah sebuah hal biasa karena menjadi sumber penularan bagi anggota kelompok masyarakat lainnya. Justifikasi seperti inilah yang keliru atau salah karena bisa saja masyarakat tidak mengerti bahwa penularan HIV itu tidak hanya melalui hubungan seksual akibat "membeli seks" tetapi ada banyak korban ODHA yang tertular akibat penyebab lain seperti jarum suntik, tranfusi darah ataupun pada bayi-bayi yang tidak berdosa karena ibunya adalah ODHA (Aisha, 2008)

\section{SIMPULAN}

Pengetahuan Tentang HIV/AIDS merupakan faktor yang paling berpengaruh terhadap stigma terhadap ODHA dengan nilai odds ratio 4,276 yang artinya responden yang memiliki pengetahuan kurang memiliki kecenderungan 4,276 kali lebih besar untuk melakukan stigma terhadap ODHA dibandingkan dengan responden yang memiliki pengetahuan baik. Pengetahuan tentang HIV/AIDS sangat mempengaruhi bagaimana individu tersebut akan bersikap terhadap ODHA. Stigma dan diskriminasi terhadap ODHA muncul 
berkaitan dengan ketidaktahuan tentang mekanisme penularan HIV, perkiraan risiko tertular yang berlebihan melalui kontak biasa dan sikap negatif terhadap kelompok sosial yang tidak proporsional yang dipengaruhi oleh epidemi HIV/AIDS ini (Mahendra, 2006).

\section{KEPUSTAKAAN}

Andrewin. Stigmatization of Patients with HIV/AIDS among Doctors and Nurses in Belize. AIDS Patient Care and STDs. 2008; 4(3): 6-12

Chin JJ. Chinese and South Asian Religious Institutions and HIV Prevention in New York City. AIDS Education and Prevention. 2005; 4(2): 1-7.

Dinas Kesehatan Kabupaten Banyumas. 2014. Data HIV/AIDS tahun 2014. Dinas Kesehatan Kabupaten Banyumas. Banyumas.

Family Health Internasional (FHI). 2007. Religious Leaders Response to HIV\&AIDS. FHI. Jakarta.

Green LW and Kreuter MW. 1999. Health Promotion Planning: An Educational And Ecological Approach (3rd). Mountain View CA. Mayfield.

Goffman E. 2003. Stigma : Notes on the Management of Spoiled Identity. Englewood Cliffs NJ. Prentice Hall.

Hurlock. 2008. Psikologi Perkembangan. Erlangga. Jakarta.

Kementerian Kesehatan Republik Indonesia. 2014. Laporan Situasi Perkembangan HIV/AIDS di Indonesia sampai Juli 2014.
Kementerian Kesehatan Republik Indonesia. Jakarta.

Kementerian Negara Pemberdayaan Perempuan Republik Indonesia (KNPPRI). 2008. Pemberdayaan Perempuan Dalam Pencegahan Penyebaran HIV - AIDS. KNPPRI. Jakarta.

Komisi Penanggulangan AIDS Nasional (KPAN). 2009. Laporan Riset Bagian I, KIE Menghapus Stigma dan Diskriminasi Terhadap ODHA di 6 Kota (Jakarta, Bandung, Surabaya, Batam, Pontianak, Jayapura). KPAN. Jakarta.

Kelly MJ. The Role of Religion in HIV\&AIDS Epidemic (With Special Reference to Christianity and Islam). Paper commissioned by UNAIDS Scenario Setting for HIV \&AIDS in Africa. 2003; 6(3): 123-140.

Lembaga Penelitian dan Pengembangan Sumber Daya Lingkungan Hidup (LPPSLH) Kabupaten Banyumas. 2014. Data Stigma terhadap ODHA Kabupaten Banyumas. LPPSLH. Banyumas.

Mahendra VS, et all. Reducing Stigma and Discrimination in Hospital: Positive Findings from India. Horizons Research Summary. 2006; 4(2): 5-14.

Nasarrudin. 2009. Argumen Kesetaraan Gender Perspektif Al-Quran. Paramadina. Jakarta.

Notoatmodjo S. 2007. Pendidikan dan Perilaku. Rineka Cipta. Jakarta.

Russel. 2011. Bebas dari 6 Penyakit Paling Mematikan. Media Pressindo. Yogyakarta. 
Pengaruh Pengetahuan terhadap ... (Misrina Retnowati, Sutopo PJ, Syamsulhuda BM)

Surapsari. 2008. Penyakit Infeksi HIV. Erlangga. Jakarta.

Samsuridjal. 2012. Penatalaksanaan Infeksi

Varas Díaz TBN, et all. Religion and HIV/AIDS Stigma: Implications for Health Professionals in Puerto HIV di Pelayanan Dasar. FKUI dan Pelita Ilmu. Jakarta.

Shaluhiyah. Stigma Masyarakat terhadap Orang Dengan HIV/AIDS. Jurnal Kesehatan Masyarakat Nasional Universitas Indonesia. 2015; 9(4): Rico. NIH Public Access Author Manuscript. 2011; 3(2): 1-10.

Wawan A. 2010. Teori Pengetahuan, Sikap dan Perilaku Manusia. Nuha Medika. Yogyakarta. 